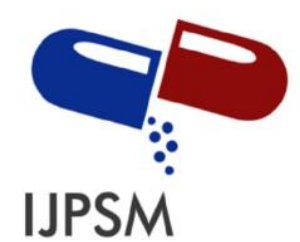

Qanita Rahmadhani et al, Int. Journal of Pharmaceutical Sciences and Medicine (IJPSM),

Vol.6 Issue. 5, May- 2021, pg. 1-11

ISSN: 2519-9889

Impact Factor: 3.426

\title{
Overview on Determination of Irbesartan Levels in Pharmaceutical Preparation and Biological Matrices
}

\author{
Qanita Rahmadhani ${ }^{1}$; Fithriani Armin ${ }^{1}$; Harrizul Rivai ${ }^{{ }^{*}}$ \\ ${ }^{1}$ Faculty of Pharmacy, Andalas University, Limau Manih Campus, Padang 25163, Indonesia \\ "Email: harrizul@yahoo.co.id and harrizul@ phar.unand.ac.id \\ DOI: 10.47760/ijpsm.2021.v06i05.001
}

\begin{abstract}
Irbesartan is classified as an angiotensin II receptor antagonist. It is used in the treatment of diseases such as hypertension and diabetic nephropathy. It is available in single and combination forms in the market. Drug quality assurance needs to be done to ensure the quality and safety of drugs, one of the quality assurance that can be done by determining the level of medicine. This review provides an analytical method for determining irbesartan levels is collected from literature in the last ten years (2011-2020) through web sources such as Science Direct, Google Scholar, PubMed, Research Gate, and others with the search keyword "Analysis of Irbesartan in Pharmaceutical Preparation and Biological Matrices" and "Determination of Irbesartan." The methods reported for the analysis of irbesartan in bulk, pharmaceutical preparations, and biological matrices. The analysis method is used, such as spectrophotometry methods, high-performance liquid chromatography (HPLC), and high-performance thin-layer chromatography (HPTLC). Overall, the most used method is high-performance liquid chromatography because not only to pharmaceutical preparations, this method can also be used for biological matrices samples that require a small amount of sample analysis.
\end{abstract}

Keywords: Irbesartan, spectrophotometry, HPLC, HPTLC, pharmaceutical preparation, biological matrices

\section{Introduction}

Irbesartan is an orally active nonpeptide tetrazole derivative. The IUPAC name for irbesartan is 2 butyl-3 - (\{4[2- (2H-1,2,3,4-tetrazole-5-il) phenyl] phenyl $\}$ methyl) -1,3-diazaspiro [4.4] non- 1-en-4-one $\left(\mathrm{C}_{25} \mathrm{H}_{28} \mathrm{~N}_{6} \mathrm{O}\right)$. The structural formula for irbesartan is shown in Figure 1 [1]. The description is white to almost white powder, difficult to dissolve in ethanol and methylene chloride, and practically insoluble in water [2].

The requirements for irbesartan levels stated in the Indonesian Pharmacopoeia, containing not less than $98 \%$ and not more than $102 \%\left(\mathrm{C}_{25} \mathrm{H}_{28} \mathrm{~N}_{6} \mathrm{O}\right)$, are calculated for anhydrous substances. The requirement for irbesartan tablets is that they contain irbesartan $\left(\mathrm{C}_{25} \mathrm{H}_{28} \mathrm{~N}_{6} \mathrm{O}\right)$ not less than $90 \%$ and not more than $110.0 \%$ of the amount stated on the label [3]. 


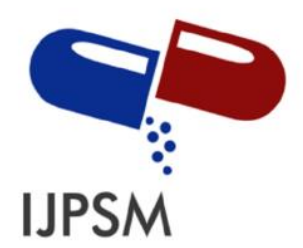

Qanita Rahmadhani et al, Int. Journal of Pharmaceutical Sciences and Medicine (IJPSM), Vol.6 Issue. 5, May- 2021, pg. 1-11

ISSN: 2519-9889

Impact Factor: 3.426

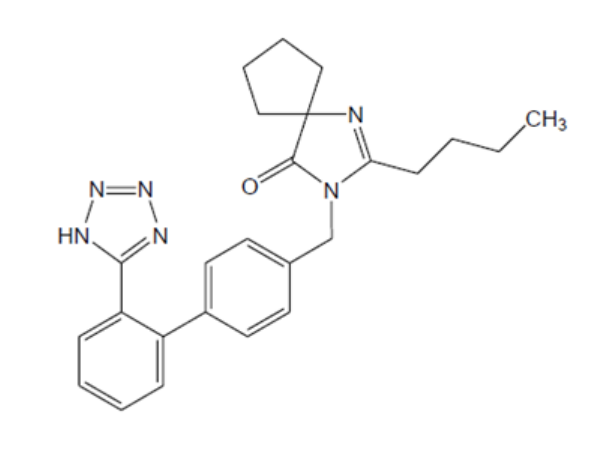

Figure 1: Structure of Irbesartan [3]

Irbesartan is an angiotensin II receptor antagonist. In the renin-angiotensin system, angiotensin I is converted into angiotensin II with the help of the angiotensin-converting enzyme (ACE). Irbesartan will inhibit the bond between angiotensin II to AT1 receptors selectively so that it can promote vasodilation and reduce the effects of aldosterone in the form of reduced-sodium excretion and increased potassium excretion [2].

This drug is used in the treatment of hypertension because it can lower blood pressure. The irbesartan tablets have trade names including Arbiten- $\mathrm{I}^{\circledR}$, Cardiocom $^{\circledR}$, Elzar $^{\circledR}$, Irbedox ${ }^{\circledR}$, with a dosage of $150 \mathrm{mg}$ and $300 \mathrm{mg}$. Irbesartan is also available as a combination tablet with the low-dose hydrochlorothiazide diuretic with the trade name Co Aprovel ${ }^{\circledR}$, Co-Irvebal ${ }^{\circledR}$, and Arbiten ${ }^{\circledR}$ with a dose of irbesartan $150 \mathrm{mg}(300 \mathrm{mg})$ and a dose of hydrochlorothiazide $12.5 \mathrm{mg}(12.5 \mathrm{mg})$ [4].

Irbesartan has $\mathrm{pKa}=4.24$, so it can dissolve in a neutral $\mathrm{pH}$ range. The partition coefficient (octanol-water) is 10.1 at $\mathrm{pH} 7.4$ [5]. Irbesartan is an active drug in its original form. It is absorbed when used orally, has a high bioavailability of $60-80 \%$, and is not affected by food. This drug is bound to plasma protein as much as $90 \%$, and plasma $\mathrm{C}_{\max }$ is reached 1.5-2 hours after oral administration. It is a lipophilic drug that has a distribution volume of 53-93 L. The drug's half-life is between 11-15 hours, so one oral administration is expected to control blood pressure within 24 hours efficiently [6].

\section{Method of Collecting Data}

In this review article, the technique used is literature study by finding sources in pharmaceutical books and international journals in the last ten years (2011-2020) through online media with the search keyword "Analysis of Irbesartan in Pharmaceutical Preparation and Biological Matrices" and "Determination of Irbesartan." The search for this review article using web sources such as Science Direct, Google Scholar, PubMed, Research Gate, and other published and trusted journals.

\section{Methods of Analysis Irbesartan}

Several methods are carried out to analyze irbesartan in raw material, pharmaceutical preparations, and biological matrices.

\subsection{Spectrophotometry}

Spectrophotometry methods have been used in irbesartan analysis in bulk and pharmaceutical preparations (Table 1). 


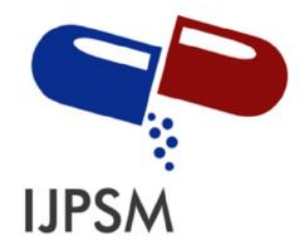

Qanita Rahmadhani et al, Int. Journal of Pharmaceutical Sciences and Medicine (IJPSM), Vol.6 Issue. 5, May- 2021, pg. 1-11

ISSN: 2519-9889

Impact Factor: 3.426

Table 1: Irbesartan analysis using spectrophotometry

\begin{tabular}{|c|c|c|c|c|c|c|}
\hline No & Sample & Solvent & Mode & Wavelength & $\begin{array}{c}\text { Range of } \\
\text { Concentration }\end{array}$ & Ref. \\
\hline 1. & $\begin{array}{l}\text { Bulk and irbesartan } \\
\text { tablet }\end{array}$ & Methanol & UV & $246 \mathrm{~nm}$ & $5-45 \mu \mathrm{g} / \mathrm{mL}$ & [7] \\
\hline 2. & $\begin{array}{l}\text { Irbesartan and } \\
\text { hydrochlorothiazide } \\
\text { combined dosage } \\
\text { tablet }\end{array}$ & $\mathrm{NaOH} 0.1 \mathrm{~N}$ & UV & $250 \mathrm{~nm}$ & $1-30 \mu \mathrm{g} / \mathrm{mL}$ & [8] \\
\hline 3. & $\begin{array}{l}\text { Bulk and irbesartan } \\
\text { tablet }\end{array}$ & $\begin{array}{l}\text { 1 M sodium } \\
\text { bicarbonate } \\
\text { solution and } 2 \\
\text { M urea solution } \\
(50 \%: 50 \% \\
\mathrm{v} / \mathrm{v})\end{array}$ & Hydrotropic & $246.4 \mathrm{~nm}$ & $10-35 \mu \mathrm{g} / \mathrm{mL}$ & [9] \\
\hline 4. & $\begin{array}{l}\text { Bulk and irbesartan } \\
\text { tablet }\end{array}$ & methanol & UV & $263 \mathrm{~nm}$ & $10-100 \mu \mathrm{g} / \mathrm{mL}$ & [10] \\
\hline 5. & $\begin{array}{l}\text { Irbesartan and } \\
\text { hydrochlorothiazide } \\
\text { combined dosage } \\
\text { tablet }\end{array}$ & methanol & UV & $205 \mathrm{~nm}$ & $5-35 \mu \mathrm{g} / \mathrm{mL}$ & {$[11]$} \\
\hline 6. & $\begin{array}{l}\text { Irbesartan and } \\
\text { hydrochlorothiazide } \\
\text { combined dosage } \\
\text { tablet }\end{array}$ & $\mathrm{NaOH} 0.1 \mathrm{~N}$ & $\begin{array}{l}\text { UV (dual- } \\
\text { wavelength) }\end{array}$ & $\begin{array}{ll}263.4 & \text { dan } \\
281 \mathrm{~nm} & \end{array}$ & $5-15 \mu \mathrm{g} / \mathrm{mL}$ & [12] \\
\hline 7. & $\begin{array}{l}\text { Bulk and irbesartan } \\
\text { tablet }\end{array}$ & methanol & Kinetic & $629 \mathrm{~nm}$ & $\begin{array}{l}5,0-40,0 \mathrm{~g} / \mathrm{mL} \\
2,0-45,0 \mathrm{~g} / \mathrm{mL}\end{array}$ & [13] \\
\hline 8. & $\begin{array}{l}\text { Bulk and irbesartan } \\
\text { tablet }\end{array}$ & $\begin{array}{ll}0.1 \% & \text { formic } \\
\text { acid } & \text { buffer } \\
\text { solution } & \end{array}$ & UV & $220 \mathrm{~nm}$ & $\begin{array}{ll}1.75- & 110.5 \\
\mu \mathrm{g} / \mathrm{mL} & \end{array}$ & [14] \\
\hline 9. & $\begin{array}{l}\text { Bulk and irbesartan } \\
\text { tablet }\end{array}$ & $\begin{array}{l}\text { Methanol and } \\
\text { acetonitrile } \\
(70: 30)\end{array}$ & $\begin{array}{l}\text { UV } \\
\text { (Zero order } \\
\text { derivative) }\end{array}$ & $207 \mathrm{~nm}$ & $1-5 \mu \mathrm{g} / \mathrm{mL}$ & [15] \\
\hline
\end{tabular}

In this study, the validation and stability test of irbesartan in pharmaceutical preparations were carried out. The UV spectrophotometric method was used in this study. This analytical method is based on monochromatic light absorption in colorless compounds in the $200-380 \mathrm{~nm}$ spectrum range - the methanol solvent selected in this experiment. The parameters of the validation method carried out include linearity, precision, accuracy, roughness, and durability. The irbesartan stability test involves forced degradation experiments in acidic, alkaline, neutral, temperature, photolytic and oxidizing conditions. The results of the study showed the maximum absorbance was at $246 \mathrm{~nm}$. Linearity was observed in the concentration range of $5-45 \mu \mathrm{g} / \mathrm{mL}$. The standard deviation and coefficient of variance were less than 2.0, which indicates the method is precise. The method's accuracy is confirmed through recovery, and results are obtained in the range of $99.335 \%$ to $100.583 \%$. The standard deviation value and the coefficient of variation are meager, indicating accurate results for the method. In the forced degradation experiment, it was found that absorption was decreased under all conditions over time, and it was found that the percentage of degradation was found. Based on the results obtained, it was found that the proposed method was accurate, precise, simple, sensitive, specific, and could be used in the quality control of irbesartan in pharmaceutical preparations.[7] 


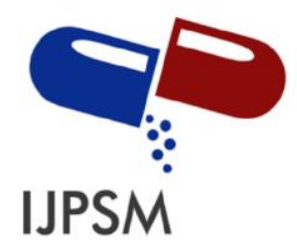
Qanita Rahmadhani et al, Int. Journal of Pharmaceutical Sciences and Medicine (IJPSM),
Vol.6 Issue. 5, May- 2021, pg. 1-11

ISSN: 2519-9889

Impact Factor: 3.426

In this study, the levels of irbesartan and hydrochlorothiazide were determined simultaneously in a combined tablet dosage form, using the UV spectrophotometric method. $0.1 \mathrm{~N} \mathrm{NaOH}$ solution was used as a solvent in this method. There are two methods to choose from in determining the levels of the combination drug irbesartan and hydrochlorothiazide. The first method is based on the simultaneous equation method, and the second method is based on $\mathrm{Q}$ analysis (absorption ratio method). Irbesartan has a maximum absorption at 250 $\mathrm{nm}$, and hydrochlorothiazide has a maximum absorption at $323 \mathrm{~nm}$ in $0.1 \mathrm{~N} \mathrm{NaOH}$. So that in the first method, the simultaneous equation method can be written as follows:

$$
\begin{aligned}
& C x=\frac{A 1 \cdot a y 2-A 2 . a y 1}{a x 1 \cdot a y 2-a y 1 \cdot a y 2} \\
& C y=\frac{A 2 . a x 1-A 1 \cdot a x 2}{a x 1 \cdot a y 2-a y 1 \cdot a y 2}
\end{aligned}
$$

Note: $\mathrm{Cx}$ and $\mathrm{Cy}$ are the concentrations of irbesartan and hydrochlorothiazide in $\mathrm{g} / 100 \mathrm{~mL}$ in the sample solution. A1 and A2 are mixed absorbances at wavelengths of $250 \mathrm{~nm}$ and $323 \mathrm{~nm}$.

Method II- absorption ratio using wavelengths of irbesartan and hydrochlorothiazide showed is absorptive at $259 \mathrm{~nm}$ and a wavelength of $323 \mathrm{~nm}$ as $\lambda$ max hydrochlorothiazide. The concentrations of the two drugs in the mixture can be calculated as follows:

$\mathrm{Cx}=\mathrm{QM}-\mathrm{QY} / \mathrm{Qx}-\mathrm{QY} \times \mathrm{A} 1 / \mathrm{ax} 1$.

$\mathrm{Cy}=\mathrm{A} 1 / \mathrm{ax} 1-\mathrm{Cx}$

Note: $\mathrm{A} 1$ and $\mathrm{A} 2$ are absorbances at $259 \mathrm{~nm}$ and $323 \mathrm{~nm}$, ax 1 and ay1 are the absorptivity of irbesartan and hydrochlorothiazide at $259 \mathrm{~nm}$, and ax 2 and ay 2 are the absorptivity of irbesartan and hydrochlorothiazide at $323 \mathrm{~nm}$.

Linearity was obtained in a concentration range of $1-30 \mu \mathrm{g} / \mathrm{mL}$ for IRB and $1-150 \mu \mathrm{g} / \mathrm{mL}$ for HCTZ. The advantages of using this method do not require special equipment. It is simple, economical, fast in sample preparation and testing, and provides accurate and precise results. This method can be used for routine quality control [8].

Determination of irbesartan levels using UV spectrophotometric methods using hydrotropic agent techniques that aim to increase water-insoluble irbesartan's solubility. This experiment using $1 \mathrm{M}$ sodium bicarbonate and $2 \mathrm{M}$ urea (50\%: 50\% v/v) as hydrotropic agents. The maximum absorbance was found at $246.4 \mathrm{~nm}$. The regression equation for the calibration curve is $\mathrm{Y}=0.0341 \mathrm{x}-0.1062$, with a correlation coefficient $(\mathrm{r}=0.9998)$, a standard deviation of 0.0075 , while the LOD and LOQ values are 1.23 and 3.72. The validation parameters tested were linearity, precision and, accuracy. The drug shows linearity over a concentration range of 10-35 $\mu \mathrm{g} / \mathrm{mL}$. The accuracy parameter can be seen from the results of the recovery percentage, which ranges from 99.4-101.3\% of the pharmaceutical sample, and the relative standard deviation percentage is in the range 0.20.4. The precision of a method is seen from the ratio of relative standard deviation (\% RSD). The analysis results for accuracy, precision, LOD, and LOQ are satisfactory. This method is simple, sensitive, and reliable with great precision and accuracy. In addition, this method is specific in determining the concentration of a formulation without the interference of excipients and other additives. This method is suitable for routine quality control analysis [9].

The ultraviolet (UV) spectrophotometric method was developed to determine irbesartan levels in pure form, formulations, and sound samples. Methanol solvent is selected in dissolving irbesartan and then detected using UV spectrophotometry with a $200-400 \mathrm{~nm}$ wavelength. The result is that the maximum absorbance is reached at a wavelength of $263 \mathrm{~nm}$. In this experiment, linearity was observed in the range of $10-100 \mu \mathrm{g} / \mathrm{mL}$ with $\mathrm{R}^{2}=$ 0.999. $\left(\mathrm{R}^{2}=\right.$ not less than 0.996$)$, by calculating the regression equation with the formula $y=m x+c$. Sandell's sensitivity in this method has obtained a value of 1.6269 . The percent purity of the three different samples, 12 , 14 , and $16 \mu \mathrm{g} / \mathrm{mL}$, was $92.44,87.49,83.47$, respectively. The retrieval percentage result shows a value of $100 \%$, which indicates that the proposed method is accurate because the results are still within official limits [10]. 


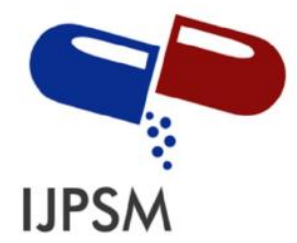

\author{
Qanita Rahmadhani et al, Int. Journal of Pharmaceutical Sciences and Medicine (IJPSM), \\ Vol.6 Issue. 5, May- 2021, pg. 1-11 \\ ISSN: 2519-9889 \\ Impact Factor: 3.426
}

The simultaneous determination of irbesartan and hydrochlorothiazide in tablets can be used with new, developed, and validated spectrophotometry. The solvent used in dissolving the sample is methanol. The maximum wavelengths of irbesartan and hydrochlorothiazide are $205 \mathrm{~nm}$ and $272 \mathrm{~nm}$, respectively. There are two methods used: the simultaneous equation formula and the absorbance ratio method (Q-analysis) in a phosphate buffer solution with a $\mathrm{pH}$ of 7.5. Simultaneous equations by selecting the maximum wavelength $(\lambda \max )$ of each drug, then calculating the absorptivity value of each spectrum. The second method is the absorbance ratio (Q-analysis) by selecting one of the drug maxima and isosbestic points, then calculating the absorption value of each spectrum. Based on these results, hydrochlorothiazide and irbesartan showed linear effects in the concentration ranges of $0.20-40 \mu \mathrm{g} / \mathrm{mL}$ and $5-35 \mu \mathrm{g} / \mathrm{mL}$ in both methods [11].

Determination of irbesartan and hydrochlorothiazide in tablets, without separation, can be done by the UV spectrophotometric method with multiple wavelengths. Drugs with these active ingredients are often combined to cause problems in quantitative analysis during quality control. The sample preparation was carried out by dissolving the sample with $0.1 \mathrm{~N} \mathrm{NaOH}$ solvent. The method used in this study was using two wavelengths of irbesartan, which showed the same absorbance to carry out an analysis of hydrochlorothiazide, and vice versa. The results obtained, multiple wavelengths were carried out at the wavelengths of 263.4 and $281 \mathrm{~nm}$ for irbesartan while for hydrochlorothiazide at 243.4 and $247.6 \mathrm{~nm}$. The concentration of irbesartan was linear at a concentration of $5-15 \mu \mathrm{g} / \mathrm{mL}$ and hydrochlorothiazide $4-12 \mu \mathrm{g} / \mathrm{mL}$. The percentage results of irbesartan recovery in three levels, $80 \%, 100 \%$, and $120 \%$, were $100.33,101.14$, and 100.29 , respectively, while for hydrochlorothiazide were 101.72, 99.64, and 99.64. The UV spectrophotometric method with multiple wavelengths successfully determined the concentration of irbesartan and hydrochlorothiazide in tablets. This method provides accurate and precise results for determining irbesartan and hydrochlorothiazide in tablet formulations without separation. It is easy to apply for routine analysis - the exciting thing about the multiple wavelength method is simple and fast [12].

Determination of irbesartan levels in raw materials and pharmaceutical preparations using the kinetic spectrophotometric method, the basis used in this method is the increase in color intensity over time. This experiment used the oxidative reaction of 3-methyl-2-benzothiazolinone hydrazone hydrochloride monohydrate (MBTH) with Ce (IV) in a $2 \%$ sulfuric acid medium. Then a diazonium salt is produced from the reagent, which is an electrical intermediate, which results in a greenish-blue product. Irbesartan has a maximum absorption capacity at $629 \mathrm{~nm}$ and is color stable for more than 1 hour. The method used in determining the concentration of irbesartan is the initial rate and fixed time (35 minutes). For the initial velocity and time specified, the results were obtained, the linearity was in the range $5.0-40.0 \mathrm{~g} / \mathrm{mL}$ and $2.0-45.0$ $\mathrm{g} / \mathrm{mL}$, the detection limits were 0.46 and $0.40 \mathrm{~g} / \mathrm{mL}$. The molar absorptivity for this method was found to be $1.50 \times 10^{4} \mathrm{~L} / \mathrm{mol} \mathrm{cm}$. The validated kinetic method can be successfully applied to IRB analysis in powder and tablet dosage forms and routine quality control analysis. The recovery percentage is above $100 \%$ for both methods [13].

Determination of irbesartan levels using UV spectrophotometric methods using $0.1 \%$ formic acid as a solvent. Determination of the maximum wavelength was observed at a wavelength of 200-400 nm, using a blank solution in the form of $0.1 \%$ formic acid. The result is that the maximum wavelength is obtained at $220 \mathrm{~nm}$. This UV spectrophotometric method was optimized in determining the content of $150 \mathrm{mg}$ irbesartan tablets, and the results of the calculation of levels were 143.67 , so that the percentage of purity was $95.78 \%$. The concentration showed linear effects in the concentration range $1.75-110.5 \mu \mathrm{g} / \mathrm{mL}$, and for the regression coefficient, the value was 0.998 . The LOD and LOQ results obtained values of $0.27 \mu \mathrm{g} / \mathrm{mL}$ and $0.82 \mu \mathrm{g} / \mathrm{mL}$. The average \% RSD for intraday and interday precision tests was found to be 0.12 and 0.17 . This precision obtained a small value of 2 , which indicates the method developed was precision. The accuracy of the procedure can be determined from the percentage of recovery, the value is $97.43 \%$, and the results fall within limits indicating that the method is accurate. A technique developed, reliable, and easy for the determination of irbesartan in large quantities and tablet dosage forms [14].

Zero-order derivative spectrophotometric methods were developed and validated to determine irbesartan in pharmaceutical raw materials and dosage forms. The maximum absorption occurs at $207 \mathrm{~nm}$ in methanol and 


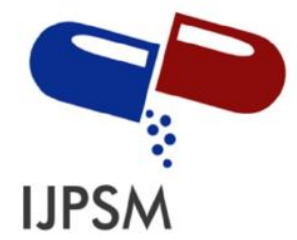

Qanita Rahmadhani et al, Int. Journal of Pharmaceutical Sciences and Medicine (IJPSM), Vol.6 Issue. 5, May- 2021, pg. 1-11

ISSN: 2519-9889

Impact Factor: 3.426

acetonitrile with a ratio of 70 : 30 . Linearity was found in the concentration range $1-5 \mu \mathrm{g} / \mathrm{mL}$, and the correlation coefficient $\left(\mathrm{r}^{2}\right)$ was 0.994 , indicating linearity, reproducibility, and precision in that range. The regression equation $\mathrm{Y}=0.1216 \mathrm{x}-0.0042$. The recovery value is $99.99-100.45 \%$, indicating this result is accurate. Results LOD $0.01647 \mu \mathrm{g} / \mathrm{mL}$ and LOQ $0.049425 \mu \mathrm{g} / \mathrm{mL}$ and $\%$ RSD value $<2$. This method has been validated following ICH guidelines for linearity, accuracy, precision, durability, roughness, LOD, and LOQ. This method is simple, fast, precise, and accurate and can be applied in the calculation of irbesartan in raw materials and pharmaceutical preparations [15].

\subsection{High-Performance Liquid Chromatography (HPLC)}

The High-Performance Liquid Chromatography method is widely used in quantitative analysis to determine irbesartan levels in pharmaceutical preparations and biological matrices (Table 2).

Table 2: Irbesartan analysis using the HPLC method

\begin{tabular}{|c|c|c|c|c|c|c|}
\hline No & Sample & Column & Mobile Phase & Detector & $\begin{array}{l}\text { Chromatographic } \\
\text { Condition }\end{array}$ & Ref. \\
\hline 1. & Human Plasma & $\begin{array}{l}4.0 \mathrm{~mm} \times 25 \mathrm{~cm} \mathrm{~L} 1 \\
\text { packing }\end{array}$ & $\begin{array}{l}\text { Phosphate buffer and } \\
\text { acetonitrile }\end{array}$ & $220 \mathrm{~nm}$ & $\begin{array}{l}\text { Flow rate } \\
1 \mathrm{~mL} / \mathrm{min}\end{array}$ & [16] \\
\hline 2. & $\begin{array}{l}\text { Irbesartan } \\
\text { Tablet }\end{array}$ & $\begin{array}{l}\text { Inertsil ODS C-18 } \\
(5 \mu \mathrm{m}, 250 \times 4.6 \\
\mathrm{mm})\end{array}$ & $\begin{array}{l}\text { methanol, acetonitrile } \\
\text { and } 2 \% \text { Ortho } \\
\text { Phosphoric Acid } \\
\text { (40: 40: 20, v / v / v). }\end{array}$ & $\begin{array}{l}\text { UV/Vis } \\
260 \mathrm{~nm}\end{array}$ & $\begin{array}{l}\text { Flow rate } \\
1,5 \mathrm{~mL} / \mathrm{min}\end{array}$ & [17] \\
\hline 3. & $\begin{array}{l}\text { Irbesartan and } \\
\text { hydrochlorothia } \\
\text { zide combined } \\
\text { dosage tablet }\end{array}$ & $\begin{array}{l}\text { Hypersil BDS RP- } \\
18,(150 \text { x } 4.6 \mathrm{~mm} \text {, } \\
5 \mu)\end{array}$ & $\begin{array}{l}\text { Sodium acetate buffer } \\
\text { solution and } \\
\text { acetonitrile } \\
(45: 55 \mathrm{v} / \mathrm{v})\end{array}$ & $\begin{array}{l}\text { UV/Vis } \\
260 \mathrm{~nm}\end{array}$ & $\begin{array}{l}\text { Flow rate } \\
1 \mathrm{~mL} / \mathrm{min}\end{array}$ & [18] \\
\hline 4. & $\begin{array}{l}\text { Simultaneous } \\
\text { tablets of } \\
\text { irbesartan and } \\
\text { hydrochlorothia } \\
\text { zide }\end{array}$ & $\begin{array}{l}\text { Hypersil BDS C18 } \\
(250 \times 4.6 \mathrm{~mm}, 5 \mu)\end{array}$ & $\begin{array}{l}\text { Acetonitrile: sodium } \\
\text { acetate anhydrous } \\
\text { buffer } \\
(55: 45 \mathrm{v} / \mathrm{v})\end{array}$ & $\begin{array}{l}\text { UV } \\
260 \mathrm{~nm}\end{array}$ & $\begin{array}{l}\text { Flow rate } \\
1 \mathrm{~mL} / \mathrm{min}\end{array}$ & [19] \\
\hline 5. & $\begin{array}{l}\text { Irbesartan and } \\
\text { hydrochlorothia } \\
\text { zide combined } \\
\text { dosage tablet }\end{array}$ & $\begin{array}{l}\text { Supelcosil C18 } \\
(150 \mathrm{~mm} \times 4.6 \mathrm{~mm} \text {, } \\
5 \mu \mathrm{m})\end{array}$ & $\begin{array}{l}\text { Methanol- } \\
\text { tetrahydrofuran- } \\
\text { acetate buffer } \\
(47: 10: 43 \mathrm{v} / \mathrm{v} / \mathrm{v}, \\
\text { pH } 6.5)\end{array}$ & $271 \mathrm{~nm}$ & $\begin{array}{l}\text { Flow rate } \\
0.75 \mathrm{~mL} / \mathrm{min} \\
\text { Temperature } \\
25^{\circ} \mathrm{C}\end{array}$ & [20] \\
\hline 6. & $\begin{array}{l}\text { Simultaneous } \\
\text { tablets of } \\
\text { irbesartan and } \\
\text { hydrochlorothia } \\
\text { zide }\end{array}$ & $\begin{array}{l}\text { Chromolith }{ }^{\circledR} \\
\text { performance RP-18e }\end{array}$ & $\begin{array}{l}\text { Phosphate buffer } \\
\text { solution (pH 4) and } \\
\text { acetonitrile (50: } 50 \text {, } \\
\mathrm{v} / \mathrm{v})\end{array}$ & $\begin{array}{l}\text { UV } \\
270 \mathrm{~nm}\end{array}$ & $\begin{array}{l}\text { Flow rate } \\
1.0 \mathrm{~mL} / \mathrm{min}\end{array}$ & [21] \\
\hline 7. & Human plasma & $\begin{array}{ll}\text { Acquity } & \text { U-HPLC } \\
\text { BEH C18 } & \\
\end{array}$ & $\begin{array}{l}\text { Acetonitrile : } \\
0.1 \% \text { formic acid }\end{array}$ & $\begin{array}{l}\text { trap } 5500 \\
\text { MS }\end{array}$ & $\begin{array}{l}\text { Flow rate } \\
0.45 / \mathrm{min} \\
\end{array}$ & [22] \\
\hline 8. & Human plasma & $\begin{array}{l}\text { Acquity UPLC BEH } \\
\text { C18 (50 mm x } 2,1 \\
\text { mm, i.d. } 1,7 \mu \mathrm{m})\end{array}$ & $\begin{array}{l}\text { Acetonitrile: } \\
\text { methanol: } 10 \mathrm{mM} \\
\text { ammonium acetate } \\
(70: 15: 15 \mathrm{v} / \mathrm{v} / \mathrm{v})\end{array}$ & $\begin{array}{l}\text { Waters } \\
\text { TQD triple } \\
\text { quadrupole } \\
\text { MS } \\
\text { detector } \\
\end{array}$ & $\begin{array}{l}\text { Flow rate } \\
0,4 \mathrm{~mL} / \mathrm{min}\end{array}$ & [23] \\
\hline 9. & $\begin{array}{l}\text { Irbesartan and } \\
\text { hydrochlorothia }\end{array}$ & $\begin{array}{l}\text { Hyper-colon } \mathrm{C} 18 \\
\text { column }(250 \mathrm{~mm} \times\end{array}$ & $\begin{array}{l}50 \mathrm{mM} \text { potassium } \\
\text { dihydrogen }\end{array}$ & $210 \mathrm{~nm}$ & $\begin{array}{l}\text { Flow rate } \\
1,3 \mathrm{~mL} / \mathrm{min}\end{array}$ & [24] \\
\hline
\end{tabular}




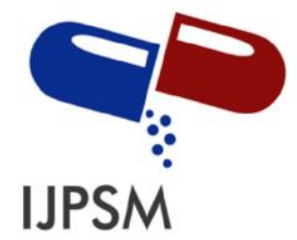

Qanita Rahmadhani et al, Int. Journal of Pharmaceutical Sciences and Medicine (IJPSM), Vol.6 Issue. 5, May- 2021, pg. 1-11

ISSN: 2519-9889

Impact Factor: 3.426

\begin{tabular}{|c|l|l|l|l|l|l|}
\hline & $\begin{array}{l}\text { zide combined } \\
\text { dosage tablet }\end{array}$ & $4.6 \mathrm{~mm}$, and $5 \mu \mathrm{m})$ & $\begin{array}{l}\text { orthophosphate : } \\
\text { acetonitrile buffer } \\
(55: 45, \mathrm{v} / \mathrm{v})(\mathrm{pH} \\
2,5) .\end{array}$ & $\begin{array}{l}\text { Temperature } \\
30{ }^{\circ} \mathrm{C}\end{array}$ & \\
\hline 10. & $\begin{array}{l}\text { Irbesartan and } \\
\text { hydrochlorothia } \\
\text { zide combined } \\
\text { dosage tablet }\end{array}$ & $\begin{array}{l}\text { X Bridge shield RP } \\
\mathrm{C}-18(150 \mathrm{~mm} \times 3,0 \\
\mathrm{mm}, 3,5 \mu \mathrm{m})\end{array}$ & $\begin{array}{l}0,1 \% \text { formic acid : } \\
\text { asetonitrile } \\
(40: 60, \mathrm{v} / \mathrm{v}),\end{array}$ & $\begin{array}{l}\text { Photodiode } \\
\text { array } \\
235 \mathrm{~nm}\end{array}$ & $\begin{array}{l}\text { Flow rate } \\
0,8 \mathrm{~mL} / \mathrm{min}\end{array}$ & {$[25]$} \\
\end{tabular}

The HPLC method was developed and validated to evaluate irbesartan in human plasma. This method is used to identify and separate irbesartan from its other components. The drug irbesartan is extracted liquid-liquid with acetonitrile (ratio 1: $1 \mathrm{v} / \mathrm{v}$ ). It can increase the recovery of the drug. Chromatographic separation used a $4.0 \mathrm{~mm} \times 25 \mathrm{~cm} \mathrm{L1}$ column. The mobile phase was used phosphate and acetonitrile buffer with a ratio of 67:33 $\mathrm{v} / \mathrm{v}$. The flow rate was $1 \mathrm{~mL} /$ minute, and the detector wavelength was $220 \mathrm{~nm}$. The method was validated and showed linearity with a concentration range of $0.1-6 \mu \mathrm{g} / \mathrm{mL}$ in plasma. The intraday and interday accuracies were $89.33 \%$ and $96.37 \%$. The intraday and interday precision were 0.02 and 2.15 , respectively. Irbesartan recovery was $97.28 \%$. The LOD and LOQ obtained were 0.05 and $0.1 \mu \mathrm{g} / \mathrm{mL}$. The advantages of this method are simple requirements, easy processing, good sensitivity, and easy handling compared to other HPLC methods [16].

The reverse-phase high-performance liquid chromatography method was developed and validated to determine irbesartan content in tablet dosage forms. Using an ODS C-18 $5 \mu \mathrm{m}$ inertsile column having an internal diameter of $250 \times 4.6 \mathrm{~mm}$ in isocratic mode with a mobile phase containing methanol, acetonitrile, and $2 \%$ OPA (40: 40: 20, v/v/v). This HPLC device is equipped with an LC-10AT (VP series) pump, SPD 10AVP UV / visible detector, and rheodyne injector (7725i). The Flow rate was $1.5 \mathrm{~mL} / \mathrm{min}$ and monitored at $260 \mathrm{~nm}$. The retention time for irbesartan was 4.5 minutes. The method is validated for linearity, accuracy, precision, specificity, detection limit, the limit of quantification, and robustness. The number of theoretical plates was 3871, which indicates the efficiency of the column performance. The calibration curve was created by describing the relationship between peak area and irbesartan concentration. The results showed linear concentrations in the range $10-70 \mu \mathrm{g} / \mathrm{mL}$, with a correlation coefficient $\left(\mathrm{r}^{2}=0.998\right)$. The regression equation of the concentration of irbesartan to the peak area is $\mathrm{y}=1.49150+5190.804 \mathrm{x}$. The RSD value for accuracy and precision obtained is less than $2 \%$, indicating this method is accurate and precise. Detection limits and quantification limits were found to be ten ng and $30 \mathrm{ng}$, respectively, which indicates the method sensitivity and irbesartan recovery from tablet formulations were found to be $100.61 \%$. These results indicate that this method is very accurate and free from the interference of formulation excipients. This method is validated, and it is found that it is simple, sensitive, accurate, and precise. Therefore the proposed method can be used for routine analysis of irbesartan determination in its tablet formulations [17].

Another developed and validated method used in simultaneous calculations in a combined preparation of irbesartan and hydrochlorothiazide is reverse phase HPLC (RP-HPLC). This method is also simple, precise, and accurate. The column was used Hypesil BDS RP-18, $150 \times 4.6 \mathrm{~mm}, 5 \mu$. The mobile phase has used a mixture of sodium acetate and acetonitrile buffer solutions (45:55). The detector is used a UV-Vis detector. Elution can be observed at $260 \mathrm{~nm}$. The flow rate was $1 \mathrm{~mL} /$ minute. In the linearity study, the correlation coefficient was found to be 0.99958 . This method is validated in the form of suitability, precision, accuracy, linearity, hardness, and durability. The acceptance criterion in this method is $\%$ RSD $<2 \%$, the correlation coefficient is not less than 0.999 . The tailings factor in the resistance test is 1.5 in the organic mobile phase variation and $\mathrm{pH}$ variation, while the $\mathrm{pH}$ variation is 2 . Based on the test results, which are still within the appropriate limits, this method is well validated. It can be used to simultaneously determine the content of irbesartan and hydrochlorothiazide in marketed drug formulations [18].

A simple and efficient reverse-phase high-performance liquid chromatography method was developed for the simultaneous determination of irbesartan and hydrochlorothiazide in tablets. This method can be used for 


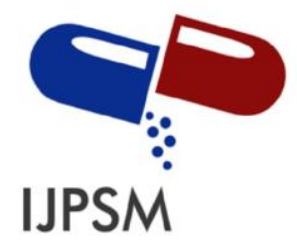
Qanita Rahmadhani et al, Int. Journal of Pharmaceutical Sciences and Medicine (IJPSM),
Vol.6 Issue. 5, May- 2021, pg. 1-11

ISSN: 2519-9889

Impact Factor: 3.426

concurrent assay of components. In this experiment, using a BDS C18 column, a hypersil package, a particle size of $250 \times 4.6 \mathrm{~mm} 5 \mu$ in isocratic mode with a mobile phase containing acetonitrile: Buffer (anhydrous sodium acetate) $(55: 45 \mathrm{v} / \mathrm{v})$ adjusted to $\mathrm{pH} 3.5$ using ortho acid phosphate. A flow rate of $1.0 \mathrm{~mL} / \mathrm{min}$ provides peak results with better resolution and is monitored at $260 \mathrm{~nm}$. The system suitability test was carried out. Viewed the parameters were in the form of a tailings factor, the number of theoretical plates, \% RSD on the condition that the acceptance of the tailings factor was not more than 2, the number of theoretical plates was not less than 2500, and the \% RSD was not more than 2. In this study, the results obtained were still within acceptable limits. The retention times and linearity ranges for irbesartan and hydrochlorothiazide were (2.98, 4.83 minutes) and (5-200, 1-400 g/mL, respectively). The method developed was accurate, precise, and selective for determining irbesartan and hydrochlorothiazide in tablet dosage forms [19].

The experimental design method used in determining the combination of irbesartan and hydrochlorothiazide using HPLC has the advantage of being able to screen multiple factors affecting response and prediction simultaneously. The three independent variable factors chosen were methanol content, mobile phase $\mathrm{pH}$, and temperature. Meanwhile, the dependent variable is the resolution, the symmetrical shape of the peaks of irbesartan and hydrochlorothiazide, and the retention factor of irbesartan and hydrochlorothiazide. In this method, the chromatographic separation of irbesartan and hydrochlorothiazide was optimized. This method also uses the desirability function by the derringer. Separation method with supelcosil column C18 (150 mm x $4.6 \mathrm{~mm}, 5 \mu \mathrm{m}$ ), mobile phase containing methanol - tetrahydrofuran - acetate buffer 47: 10: $43 \mathrm{v} / \mathrm{v} / \mathrm{v}, \mathrm{pH} 6.5$ and column temperature $25^{\circ} \mathrm{C}$, flow rate $0.75 \mathrm{~mL} /$ minute [20].

The method used to analyze the combination tablet of irbesartan and hydrochlorothiazide is HPLC with a monolithic column. Optimal chromatographic separation of analytes was achieved on the Chromolith® Performance RP-18e column using a mobile phase consisting of a buffer solution/phosphate buffer with $\mathrm{pH} 4$ and acetonitrile with a ratio $(50: 50, \mathrm{~V} / \mathrm{V})$ which was pumped isocratically with a flow rate of $1.0 \mathrm{~mL} / \mathrm{minute}$. The eluted analyte is monitored with a UV detector at $270 \mathrm{~nm}$. Under optimum chromatographic conditions, a linear relationship with a good correlation coefficient $(R \geq 0.9997)$ was found between the peak area and the irbesartan concentration ranges of 10-200 and 1-20 ng/mL hydrochlorothiazide. LOD irbesartan and hydrochlorothiazide were 2.34 and $0.03 \mathrm{ng} / \mathrm{mL}$. The resulting precision is very satisfying because the RSD does not exceed 3\%. The accuracy of this method is $>97 \%$. This method of analysis is simple and requires a short time $<3$ minutes. The advantage of using an analytical column is its good resolution strength even when the flow rate is raised, besides the water-tolerant nature of this column which is helpful in the analysis of hydrophilic compounds. The results show that the method is applicable in the quality control of combined pharmaceutical tablets containing irbesartan and hydrochlorothiazide [21].

An ultra-high performance tandem mass spectrometry (U-HPLC-MS/MS) liquid chromatography method was developed and validated to determine irbesartan (IRB) and hydrochlorothiazide (HCTZ) in human plasma simultaneously. Plasma samples were prepared using protein precipitation with acetonitrile, two analytes, and internal standard losartan were separated on the Acquity U-HPLC BEH C18 column. Mass spectrometric analysis was carried out using a QTrap5500 mass spectrometer coupled with an electrospray ionization source (ESI) in negative ion mode. The mobile phase used acetonitrile and $0.1 \%$ formic acid. The flow rate is used at $0.45 \mathrm{~mL} /$ minute. The MRM m/z transitions $427.2 \rightarrow 206.9$ and $\mathrm{m} / \mathrm{z} 296.1 \rightarrow 204.9$ were used to calculate the IRB and HCTZ. The linearity of this method was found in the concentration range of 5-3000 $\mathrm{ng} / \mathrm{mL}$ for IRB and $0.5-300 \mathrm{ng} / \mathrm{mL}$ for HCTZ in human plasma. The lower limits of quantification (LLOQ) were $5 \mathrm{ng} / \mathrm{mL}$ and $0.5 \mathrm{ng} / \mathrm{mL}$ for IRB and HCTZ in human plasma, respectively. The intra and inter precision relative standard deviation (RSD) was less than $12 \%$ for IRB and HCTZ. The method was developed and validated successfully applied to the study of IRB bioequivalence $(300 \mathrm{mg})$ with HCTZ tablets $(12.5 \mathrm{mg})$ in healthy volunteers $(\mathrm{N}=$ 20). The advantage of this method is simple sample preparation, short analysis time of 2.5 minutes per sample. This method is suitable for application purposes in the bioavailability, pharmacokinetics, and bioequivalence profiles [22].

In high-speed liquid chromatography separation and ultra-performance of tandem mass spectrometry, Liquid chromatography (UPLC-MS/MS) is a fast and superior biomedical analysis tool. A specific MS/MS ultra- 


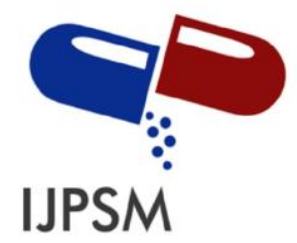

Qanita Rahmadhani et al, Int. Journal of Pharmaceutical Sciences and Medicine (IJPSM), Vol.6 Issue. 5, May- 2021, pg. 1-11

ISSN: 2519-9889

Impact Factor: 3.426

performance liquid chromatography method was developed and validated for irbesartan (IRB) in human plasma. After simple protein deposition using methanol and acetonitrile, IRB and standard internal telmisartan (IS) were separated on the Acquity UPLC BEH C18 column $(50 \mathrm{~mm} 2.1 \mathrm{~mm}$, i.d. $1.7 \mu \mathrm{m})$, which was equipped with a Waters TQD triple quadrupole MS detector. This method uses a mobile phase consisting of acetonitrile: methanol: $10 \mathrm{mM}$ ammonium acetate $(70: 15: 15 \mathrm{v} / \mathrm{v} / \mathrm{v})$ with a $0.4 \mathrm{~mL} / \mathrm{minute}$ flow rate that detects MS/MS in negative ion mode. The ion transitions noted in some reactions are $\mathrm{m} / \mathrm{z} 427.2 \rightarrow 193.08$ for IRB and $\mathrm{m} / \mathrm{z} 513.2 \rightarrow 469.3$ for standard internals. The assay showed a linear range from 2 to $500 \mathrm{ng} / \mathrm{mL}$ for IRB in human plasma with a good correlation coefficient of (0.995) and a lower limit of the quantity of $2 \mathrm{ng} / \mathrm{mL}$. The intra assay and inter-assay precision were satisfactory. The relative standard deviation did not exceed $9.91 \%$. The proposed UPLC-MS/MS method is simple, fast, and highly sensitive, and therefore reliable for pharmacokinetic and toxicokinetic studies in animals and humans [23].

The RP-HPLC method is described and validated for the simultaneous determination of hydrochlorothiazide (HCTZ) and irbesartan (IRB) in combined pharmaceutical preparations. In this study, hydrochlorothiazide and irbesartan were degraded under different pressure test conditions. The degraded samples were used to develop stability in determining irbesartan and hydrochlorothiazide using the high-performance liquid chromatography (HPLC) method. The two drugs were separated from the degradation products using a Hypercolon C18 reverse-phase analytical column $(250 \mathrm{~mm} \times 4.6 \mathrm{~mm}$, and $5 \mu \mathrm{m})$ and a mobile phase consisting of $50 \mathrm{mM}$ potassium dihydrogen orthophosphate: acetonitrile buffer $(55: 45, \mathrm{v} / \mathrm{v})(\mathrm{pH} 2.5)$. The instrument settings were optimized at a flow rate of $1.3 \mathrm{~mL} / \mathrm{min}$, a column temperature of $30^{\circ} \mathrm{C}$, a detection wavelength of $210 \mathrm{~nm}$, and an injection volume of $20 \mu \mathrm{L}$. The retention times for HCTZ and IRB were approximately 3 and 5.2 minutes, respectively. The methods are validated for linearity, precision, accuracy, specificity, ruggedness, and durability. The results show that the method is suitable for quantitative analysis of HCTZ and IRB in the presence of degradation products due to various stress conditions. This method has the advantage of being economical because of the short running time and reducing the use of solvents compared to other methods [24].

The RP-HPLC method was developed for the determination of irbesartan and hydrochlorothiazide in combination tablets. Chromatographic separation was achieved on the X Bridge shield RP C-18 column (150 $\mathrm{mm} \times 3.0 \mathrm{~mm}, 3.5 \mu \mathrm{m}$ ) in high-performance liquid chromatography with Empower2 software and a photodiode array detector, maintained at $45^{\circ}$ C. $0.1 \%$ formic acid: acetonitrile $(40: 60$, v/v), with a flow rate of $0.8 \mathrm{~mL} / \mathrm{min}$ (ultraviolet detection at $235 \mathrm{~nm}$ ). The results obtained by IRB and HCTZ obey the Lambert-Beer law in the concentration ranges of $1.2-560 \mu \mathrm{g} / \mathrm{mL}$ and $2-600 \mu \mathrm{g} / \mathrm{mL}$. The IRB regression equation $\mathrm{y}=18222 \mathrm{x}+18180$ (IRB) $\left(\mathrm{R}^{2}=0.9997\right)$ and HCTZ $\mathrm{y}=10669 \mathrm{x}-2468(\mathrm{HCTZ})\left(\mathrm{R}^{2}=0.9999\right)$. The limits of quantification (LOQ) and limits of detection (LOD) for IRB were found to be $1.056 \mu \mathrm{g} / \mathrm{mL}$ and $0.349 \mu \mathrm{g} / \mathrm{mL}$, while the LOQ and LOD for HCTZ were found to be $1.980 \mu \mathrm{g} / \mathrm{mL}$ and $0.654 \mu \mathrm{g} / \mathrm{mL}$, respectively. IRB and HCTZ undergo acidic, alkaline, and oxidation degradation conditions. Forced degradation research was carried out using $\mathrm{HCl}, \mathrm{NaOH}$, and $\mathrm{H}_{2} \mathrm{O}_{2}$. The conclusion is HCTZ and IRB are slightly sensitive to alkaline conditions compared to other degradations [25].

\subsection{High-Performance Thin Layer Chromatography (HPTLC)}

HPTLC can-do determination of irbesartan and hydrochlorothiazide levels in pharmaceutical preparations. This experiment using a stationary phase of silica gel $60 \mathrm{~F}_{254}(10 \times 10 \mathrm{~cm})$ and a mobile phase consisting of acetonitrile: ethyl acetate $(8: 2 \mathrm{v} / \mathrm{v})$. The TLC plates were pre-washed with methanol and activated in an oven at $500{ }^{\circ} \mathrm{C}$ for 5 minutes before chromatography. The mobile phase has used a mixture of acetonitrile: ethyl acetate $(8: 2 \mathrm{v} / \mathrm{v})$. Spot detection was carried out at $260 \mathrm{~nm}$. The method was validated in terms of linearity, accuracy, precision, and specificity. Linear calibration curves range from 100-600 ng/spot for irbesartan and $50-250 \mathrm{ng} / \mathrm{spot}$ for hydrochlorothiazide. The detection and quantification limits of irbesartan were 22.19 and $73.98 \mathrm{ng} / \mathrm{spot}$, respectively, and for hydrochlorothiazide 12.42 and $41,394 \mathrm{ng} / \mathrm{spot}$, respectively. The sample solution was seen on a TLC plate with the aid of the Linomat V spotting system. The amount of drug present was calculated by comparing the value of the standard peak area with the sample. The measured results show 


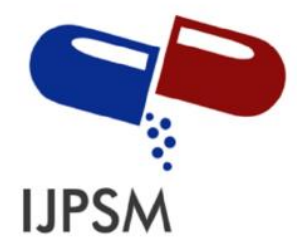

Qanita Rahmadhani et al, Int. Journal of Pharmaceutical Sciences and Medicine (IJPSM), Vol.6 Issue. 5, May- 2021, pg. 1-11

ISSN: 2519-9889

Impact Factor: 3.426

the method is precise, accurate, and linear over the range of concentrations tested with a correlation coefficient of 0.999 for both drugs and indicates an acceptable limit of RSD. The advantage of this method is that it is fast, selective, requires simple sample preparation. In addition, lower solvent consumption, so it is more costeffective [26].

\section{Conclusion}

The methods reported for the analysis of irbesartan in raw materials, pharmaceutical preparations, and biological matrices include spectrophotometric methods, High-Performance Liquid Chromatography (HPLC), High-Performance Thin Layer Chromatography (HPTLC). Overall, the most widely used method is HighPerformance Liquid Chromatography (HPLC). In addition to pharmaceutical preparations, it can also be used for biological matrices samples that require a small amount of sample analysis.

\section{References}

[1]. Borghi C, Urso R, Cicero AFG. The Cost of Effectiveness of Irbesartan for Hypertension. Expert Rev Pharmacoecon Outcomes Res. 2015;15(2):199-207.

[2]. Virani P, Rajani S, Hasumati R, Jain V. Irbesartan: A Review on Analytical Methods and its Determination in Pharmaceuticals and Biological Matrix. Inventi Rapid Pharm Analysis Quality Assurance. 2014;(4):1-8.

[3]. Kemenkes RI. Farmakope Indonesia. VI. Jakarta: Direktorat Jendral Bina Kefarmasian dan Alat Kesehatan Republik Indonesia; 2020. 758-760 p.

[4]. Ikatan Apoteker Indonesia. ISO (Informasi Spesialite Obat Indonesia). Vol 51. Jakarta: PT. ISFI Penerbitan; 2017. 303-305 p.

[5]. Husain A, Azim MS, Mitra M, Bhasin PS. a Review of Pharmacological and Pharmaceutical. Pharmacophore. $2011 ; 2(6): 240-250$.

[6]. Borghi C, Cicero AFG. The Role of Irbesartan in the Treatment of Patients with Hypertension: a Comprehensive and Practical Review. High Blood Press Cardiovascular Prevention. 2012;19(1):19-31.

[7]. Pradhan KK, Mishra US, Pattnaik S, Mishra D, Panigrahi G, Sahu KC. Method development, Validation, and Stability Study of Irbesartan in Bulk and Pharmaceutical Dosage Form by UV-Spectrophotometric method. International Journal of Pharmaceutical \& Biological Archives. 2011;2(4):1114-1122.

[8]. Todkari VB, Mahale MV, Kane SR, Mohite SK, Magdum CS. Development and validation of simultaneous spectrophotometric estimation of Irbesartan and Hydrochlorothiazide in the tablet dosage form. Journal of Pharmacy Research. 2012 Apr;5(4):2335-7.

[9]. Nissankararao S et al. Estimation of Irbesartan in Bulk and Dosage Forms by New Simple UV Spectrophotometry Using Hydrotropic Technique. Pharmaceutica Analytica Acta. 2013;04(08):8-10.

[10]. Banjare L, Chandra JK, Patel P. Method Development And Validation for Estimation of Irbesartan in Bulk Drug And Pharmaceutical Dosage. Journal of Drug Delivery \& Therapeutics. 2013;3(6):87-90.

[11]. Phani Kumar JS, Mathrusri Annapurna M. New Spectrophotometric Methods for the Simultaneous Determination of Irbesartan and Hydrochlorothiazide in Combined Dosage Forms. Pharmaceutical Methods. 2015;6(3):120-125.

[12]. Hafid S, Maria M. Determination of Simultaneous Irbesartan and Hydrochlorothiazide by Ultraviolet Spectrophotometry with Dual Wavelength Method. Asian Journal of Pharmaceutical Research and Development. 2019;7(3):1-4.

[13]. Ashour S, Bayram R. Selective and Validated Kinetic Spectrophotometric Method for The Determination of Irbesartan in Pure and Pharmaceutical Formulations. Annales Pharmaceutical Francaises. 2018;77(2):101-111.

[14]. Mondal S, Pal A, Mondal P, Shit D, Biswal S, Mohan Babu B. Determination of Irbesartan Using Stability Indicating Reverse Phase Liquid Chromatographic and UV Spectrophotometric Method. International Journal of Pharmaceutical Investigation. 2020;10(1):70-75.

[15]. Yogeesh CS, Sowmya HG, C Jose GB. New Analytical Method Development and Validation for Irbesartan in Bulk and Tablet Dosage Form by Using UV-Spectrophotometric Method. International Journal of Pharmacy and Pharmaceutical Analysis. 2020;04(01):12-16.

[16]. Zeb-Un-Nisa, Ali SI, Rizvi M, Khan MA, Sultan RA, Fatima R, et al. Development and Validation of Reverse Phase HPLC Method for Determination of Angiotensin Receptor Blocking Agent Irbesartan in Plasma. Pakistan Journal of Pharmaceutical Sciences. 2019;32(2):853-858. 


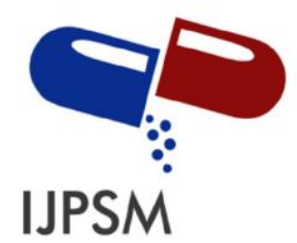

Qanita Rahmadhani et al, Int. Journal of Pharmaceutical Sciences and Medicine (IJPSM), Vol.6 Issue. 5, May- 2021, pg. 1-11

ISSN: 2519-9889

Impact Factor: 3.426

[17]. Raju RR, Bujji Babu N. Development and Validation of HPLC Method The Estimation of Irbesartan in Pharmaceutical Dosage Form. Pharmacophore. 2011;2(2):108-112.

[18]. Raja B, Himasri P, Ramadevi B. RP-HPLC Method for The Simultaneous Estimation of Irbesartan and Hydrochlorothiazide in Pharmaceutical Dosage Form. International Research Journal of Pharmaceutical and Applied Sciences. 2012;2(3):29-38.

[19]. Edwards MM, Chary TN, Junapudi S, Sushma M. RP-HPLC Method Development and Validation for Simultaneous Estimation of Irbesartan and Hydrochlorothiazide in Pharmaceutical Dosage Form. Asian J Research Chemistry. 2012;5(4).

[20]. Vujić Z, Mulavdić N, Smajić M, Brborić J, Stankovic P. Simultaneous Analysis of Irbesartan and Hydrochlorothiazide: an Improved HPLC Method with The Aid of a Chemometric Protocol. Molecules. 2012;17(3):3461-3474.

[21]. Alanazi AM, Abdelhameed AS, Khalil NY, Khan AA, Darwish IA. HPLC Method with Monolithic Column for Simultaneous Determination of Irbesartan and Hydrochlorothiazide in Tablets. Acta Pharm. 2014;64(2):187-198.

[22]. Qiu X, Wang Z, Wang B, Zhan H, Pan X, Xu R ai. Simultaneous Determination of Irbesartan and Hydrochlorothiazide in Human plasma by Ultra-High-Performance Liquid Chromatography-Tandem Mass Spectrometry and Its Application to a Bioequivalence Study. Journal of Chromatography B: Analytical Technologies in The Biomedical Life Sciences. 2014;957:110-115.

[23]. Wani TA, Zargar S. New Ultra-performance Liquid Chromatography-tandem Mass Spectrometry Method for the Determination of Irbesartan in Human Plasma. Journal of Food and Drug Analysis. 2015;23(3):569-576.

[24]. Ali TA, Mohamed GG, Aglan AA, Heakal FET. RP-HPLC Stability-indicating Method for Estimation of Irbesartan and Hydrochlorothiazide in Bulk and Pharmaceutical Dosage Form. Chinese Journal of Analytical Chemistry. 2016;44(1):1601-1608.

[25]. Srinivasu T, Annapurna MM. Development of a New Validated Stability Indicating RP-HPLC Method for Determination of Irbesartan and Hydrochlorothiazide. Asian Journal of Pharmaceutics. 2018;12(1).

[26]. Rosangluaia, Shanmugasundaram P, Velraj Malarkodi. Validated HPTLC Method for Simultaneous Estimation of Irbesartan and Hydrochlorothiazide in a Tablet Dosage Form. Der Pharma Chemica. 2011;3(5):310-317.

\section{A Brief Author Biography}

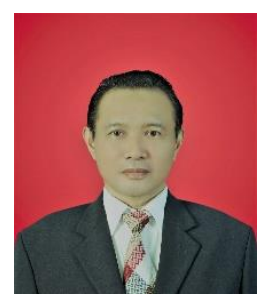

Prof. Dr. Harrizul Rivai, M.S., was born in Payakumbuh, West Sumatra, on 4 September 1953. His father is Rivai Said, and his mother is Saridahanum Syofyan. The Author obtained a Bachelor of Pharmacy from the Department of Pharmacy, Faculty of Mathematics and Natural Sciences, Padjajaran University, Bandung (1976), a Master of Science degree from the Bandung Institute of Technology (1984), and a Doctorate from the Department of Chemistry, Faculty of Mathematics and Natural Sciences, Andalas University, Padang (2011). Now the Author is a Professor and Researcher at the Faculty of Pharmacy, Andalas University, Padang. The Author also serves as Deputy Chair of Academic Affairs at the YPTIK Padang College of Pharmacy (STIFARM). The Author wrote the book "Principles of Chemical Examination" (Publisher UI-Press, 1995), translated the book "Pharmaceutical Statistics" (EGC Medical Book Publishers, 2010), and wrote "Chapter 4" in the book "Recent Research Advances in Biology Vol. 4" (International Book Publisher, India, and United Kingdom, 2020), and wrote the book "Chinese Petai (Leucaena leucocephala): Traditional Uses, Phytochemicals, and Pharmacological Activities" (Deepublish, Yogyakarta, 2021). The Author wrote "Chapter 9" in the book "Recent Research Advances in Biology Vol. 7" (International Book Publisher, India, and United Kingdom, 2021). The Author has also written articles in various international journals in various science fields, such as chemistry, biology, and pharmacy. 